TITLE:

\title{
Open-cell foams of polyethylene terephthalate/bisphenol a polycarbonate blend
}

$\operatorname{AUTHOR}(\mathrm{S}):$

Gong, Pengjian; Ohshima, Masahiro

CITATION:

Gong, Pengjian ...[et al]. Open-cell foams of polyethylene terephthalate/bisphenol a polycarbonate blend. Polymer Engineering \& Science 2014, 55(2): 375-385

\section{ISSUE DATE:}

2014-03-02

URL:

http://hdl.handle.net/2433/200220

\section{RIGHT:}

This is the peer reviewed version of the following article: Gong. P. and Ohshima, M. (2015). Open-cell foams of polyethylene terephthalate/bisphenol a polycarbonate blend. Polym Eng Sci, 55: 375-385, which has been published in final form at http://dx.doi.org/10.1002/pen.23894. This article may be used for non-commercial purposes in accordance with Wiley Terms and Conditions for Self-Archiving.; この論文は出版㭊版でありません。引用の際には出版社版をご確 認ざ利用ください。;This is not the published version. Please cite only the published version. 
1 Open-cell Foams of Polyethylene Terephthalate/Bisphenol A

2 Polycarbonate Blend

3 Authors: Pengjian Gong and Masahiro Ohshima

4 Affiliation: Department of Chemical Engineering, Kyoto University 


\section{Open-cell Foams of Polyethylene Terephthalate/Bisphenol A}

\section{Polycarbonate Blend}

$3 \quad$ Pengjian Gong and Masahiro Ohshima

4 Department of Chemical Engineering, Kyoto University, Kyoto 615-8510, Japan

5 Correspondence to: M. Ohshima (E-mail: ohshima.masahiro.2w@kyoto-u.ac.jp)

7 ABSTRACT

8 Open microcellular foams of polyethylene terephthalate (PET)/polycarbonate (PC) blends

9 were prepared by controlling their foaming behavior at the interface between these two

10 polymers. Interface modification was a crucial factor in governing the foaming behavior

11 and cell morphology of the blend foams: annealing at $280^{\circ} \mathrm{C}$, i.e., conducting the

12 transesterification reaction, generates a PET-b-PC copolymer, which lowers the

13 interfacial tension, increases the affinity between PET and PC, and decreases the

14 crystallinity of the PET domains. When $\mathrm{CO}_{2}$ foaming was performed at the interface

15 modified with the copolymer, an interesting fibril-like structure was formed. The cell

16 density of the PET/PC blend then increased, and its cell size reduced to the microscale

17 while maintaining a high open-cell ratio. The effect of heat annealing (transesterification

18 reaction) on $\mathrm{CO}_{2}$-foaming was studied to reveal the relationship among the interface

19 affinity, crystallinity, and degree of fibrillation. The optimal heat-annealing procedure

20 generated a fibril-like structure in the PET/PC blend foams with a high cell density

$21\left(7 \times 10^{11} \mathrm{H} \mathrm{cm}^{-3}\right)$, small cell size (less than $\left.2 \mu \mathrm{m}\right)$, and $100 \%$ open-cell ratio.

23 KEYWORDS annealing; blends; copolymers; open-cell foam; fibril-like structure; 


\section{INTRODUCTION}

Polymeric foams have versatile thermal and mechanical properties, and they can

4 be applied to many plastic parts. The application depends on the cell morphology of the

5 foams, which is characterized by the cell density, cell size, and open and/or closed-cell

6 structures. [1] The polymeric foams used for construction, packaging, and heat insulation

7 are commonly made of closed-cell foams. [2] The foams used for shock absorption,

8 sound attenuation, battery separators, and cell-scaffolds for tissue engineering are

9 normally made of open-cell foams. [3-5]

Several cell-opening strategies have been proposed in the field of physical

11 foaming, such as creating high temperature differences between the surface and core of

12 an extrudate, using mixed blowing agents to induce secondary nucleation and to change

13 the cell densities, using interpolymer blending, and blending two polymers with different

14 crystallization temperatures. [6-10] Lee et al. prepared open-cell foams from

15 polyethylene (PE) and polypropylene (PP) blends by extrusion. [9] They proposed two

16 strategies to open the cell wall of the thermoplastic polymer foams: i) The polymer

17 blends were prepared so that their dispersed domains could be composed of a low- $\mathrm{T}_{\mathrm{C}}$

18 (soft) polymer and the matrix could be composed of a high- $\mathrm{T}_{\mathrm{c}}$ (hard) polymer. Cell

19 opening was then initiated through the soft domains trapped between growing adjacent

20 cells. ii) The polymer blends were prepared so that their dispersed domains could be

21 composed of a high- $\mathrm{T}_{\mathrm{C}}$ (hard) polymer and the matrix could be composed of a low- $\mathrm{T}_{\mathrm{C}}$

22 (soft) polymer. Cell opening was then initiated by debonding the interface between the

23 hard domains and the soft matrix. Lee et al. incorporated a secondary blowing agent to 
1 further plasticize the soft regions so that the stiffness contrast between the hard and soft

2 regions in the polymer blend could be intensified. [7] Kohlhoff et al. used an

3 interpenetrating network structure to increase the stiffness contrast between the domain

4 and matrix and prepared open cellular polylactic acid (PLA)-based blends, in which the

5 monomer acted as another cell-opening agent. [8] To prepare open cellular homopolymer

6 foams, the hard/soft inhomogeneity strategy could be extended to a

7 crystalline/amorphous structure. Semi-crystalline polymers, such as PP, have a hard

8 region in the crystallite and a soft region in the amorphous area. Miyamoto et al. used a

9 crystalline nucleating agent for PP to form three-dimensional network of highly

10 connected nano-fibrils by foaming. [11] The network maintained the cellular size at the

11 nano/microscale level and opened the cell walls by debonding the lamellae from the

12 inter-lamellar amorphous region. Another cell-opening method was reported by Krause et

13 al. [12] They prepared an open cellular polysulfone (PSU) film using $\mathrm{CO}_{2}$ and 14 tetrahydrofuran (THF) as a blowing agent. During foaming, the cell wall thickness

15 fluctuated, and the degree of fluctuation was facilitated by THF. Consequently, the cell

16 walls were open, and the foam featured nanopores. The authors extended their study to

17 obtain open nanoporous polymers and polymeric blends by $\mathrm{CO}_{2}$ foaming. $[13,14]$ Their

18 open nanoporous morphology on the cell wall seemed to be a function of cell wall

19 stretching and certain inhomogeneities in the structural or physical properties. However,

20 the relationship was not clarified, and the mechanism of transition from closed to open

21 cells remained uncertain.

Cell sizes have also been reduced in the foaming industry for the production of

23 microcellular foams. The prevention of cell coalescence was one of the key factors in 
1 reducing the cell size. Cell coalescence and cell size in physical foaming are commonly

2 reduced by increasing the viscosity of the matrix polymer and enhancing the strain

3 hardening behavior. $\mathrm{Li}$ et al. numerically simulated polymer foaming to study the

4 dynamics and stability of bubble growth. [15] They found that the stability of bubbles

5 was controlled by the strain hardening characteristics and elastic properties of the

6 polymers. Cross-linking agents and highly viscous components have been used and

7 proven effective to increase the viscoelasticity and suppress cell coalescence. [16, 17]

8 Carbon nanotube, nanoclay, and long-chain branched polymers could also be used to

9 control the viscoelasticity and reduce the cell size. [18-20] They can orient the polymer

10 chains in biaxial elongational flow and increase viscoelasticity locally at the cell wall. To

11 produce open porous microcellular foam, the cell size is reduced while simultaneously

12 opening or rupturing the cell wall. The increase in viscoelasticity and introduction of

13 strain hardening behavior or local polymer orientation can reduce the cell size but might

14 not enhance cell opening. A different strategy is necessary to reduce the cell size,

15 increase the cell density and simultaneously enhance the degree of cell opening.

16 In this study, the heterogeneous interface was focused on as the site for cell

17 opening. Instead of making the clear contrast between soft and hard domains in the

18 polymer blends, the interfacial properties between the two domains were obscured for

19 cell opening and microcellular foaming. The effect of the interfacial properties on the

20 foaming behavior has been widely investigated. [21-24] Decreasing the interfacial

21 tension between the domain and matrix polymers can increase the compatibility between

22 two polymers and increase the interfacial area, which increases the number of

23 heterogeneous nucleation sites. Conversely, decreasing the interfacial tension reduces the 
1 heterogeneity between the domain and matrix polymers and suppresses the bubble

2 nucleation rate at the interface. [25] Therefore, decreasing the interfacial tension provides

3 positive and negative effects on bubble nucleation. Furthermore, decreasing the

4 interfacial tension can increase the interfacial affinity and lead to a fibril structure that

5 connects the semi-crystalline domains and matrix polymers. [26] Consequently, an

6 optimal interfacial property may exist for microcellular foam with a high open-cell ratio.

Interface modification is a common method for controlling the interfacial tension

8 and blend morphology. In this study, polyethylene terephthalate (PET)/polycarbonate

9 (PC) blends were used to prepare the open porous microcellular foam. In our system,

10 PET dispersed domains were used as bubble nucleating agents. The miscibility between

11 PET and PC was changed by a copolymer produced during the transesterification reaction.

$12[27,28]$ The presence of a copolymer at the interface can locally reduce the polymer

13 viscoelasticity at the interface, facilitate stretching, and open the cell wall around the PET

14 domains with a fibrillated structure. The fibrillation at the interface may also lead to a

15 stretch-induced void formation mechanism, which increases the cell density. Therefore, a

16 novel method was reported in this study to control $\mathrm{CO}_{2}$ foaming with optimal interfacial

17 properties to achieve a designated foam morphology, such as small cell size, large cell

18 density, and large open-cell ratio.

20 EXPERIMENTAL

\section{Materials}

PC (Idemitsu, Taflon A2600, $\mathrm{M}_{\mathrm{w}}=32,000, \mathrm{MFR}=6 \mathrm{~g} 10-\mathrm{min}^{-1}\left(300^{\circ} \mathrm{C} 1.2 \mathrm{~kg}\right)$ )

23 and PET (Mitsui Chemical, J125, $\mathrm{M}_{\mathrm{w}}=56,000$, inherent viscosity=0.75 $\mathrm{dl} \mathrm{g}^{-1}$ ) were used 
1 as received. $\mathrm{CO}_{2}$ (99.95\% purity, Showa-Tansan, Japan) was used as the physical

2 foaming agent.

3 Preparation of PET/PC blends

PET and PC pellets were dried in a vacuum oven at room temperature for at least 2 days. They were dry-mixed at two different weight ratios of PET to PC (10/90 and

6 30/70) and fed into a melt mixer (Labo Plastomill, 4C150 Toyoseiki, Japan). After melt

7 blending, the PET/PC blend was placed in a vacuum oven for another 2 days to remove

8 moisture. The blend was then annealed in an oven at $280^{\circ} \mathrm{C}$ for two different time periods

9 (1 and $5 \mathrm{~h}$ ) with a nitrogen purge (heat-annealing process). The transesterification degree

10 was controlled by changing the heat-annealing time. The transesterification reaction can

11 be accelerated by a variety of catalysts, such as lanthanides, titanium and

12 calcium/antimony. [29-31] However, the residual catalysis in PET could carry out the

13 reaction in this study. Therefore, no external catalyst was introduced into our system.

14 Because the PET domain could aggregate when PET/PC 30/70 wt\% blends were heat-

15 annealed, the blends were again melt-mixed to increase the dispersion of the PET

16 domains in PC. The sample ID., heat-annealing times, and weight ratios of PET/PC

17 blends are summarized in Table 1.

18 The first melt-mixing was conducted at $270^{\circ} \mathrm{C}$ by rotating a kneading rotor at 10

$19 \mathrm{rpm}$ for the first $2 \mathrm{~min}$. The rotation speed was then increased to $50 \mathrm{rpm}$ for the next 8

$20 \mathrm{~min}$. The second melt-mixing was conducted at $10 \mathrm{rpm}$ for $2 \mathrm{~min}$, followed by $50 \mathrm{rpm}$ for

213 min. After mixing, the blends were molded into a plate shape using a hot compression

22 molding machine.

$23 \quad \mathrm{CO}_{2}$ foaming 
The PET/PC blend samples were placed in a high-pressure autoclave to dissolve the $\mathrm{CO}_{2}$ at $10 \mathrm{MPa}$ for $22.3 \mathrm{~h}$ at $60^{\circ} \mathrm{C}$. After removing the sample from the autoclave without foaming, it was immediately placed on an aluminum plate and foamed on the hot press by heating for $1 \mathrm{~min}$ at three different foaming temperatures: 80,120 and $150^{\circ} \mathrm{C}$. The sorption time was fixed at $22.3 \mathrm{~h}$ to ensure that all blends reached an equilibrium state with $\mathrm{CO}_{2}$.

\section{Characterization of PET/PC blend rheological properties and crystallinity}

The rheological properties were measured using a rheometer (Advanced Rheometric Expansion System, ARES, TA Instruments, USA): Rectangular torsion geometry was used to conduct dynamic temperature ramp tests from 40 to $200^{\circ} \mathrm{C}$ at a heating rate of $2^{\circ} \mathrm{C} \mathrm{min}^{-1}$. The constant oscillation frequency of the torsion bar was set to $1 \mathrm{rad} \mathrm{s}^{-1}$ with $0.1 \%$ constant strain. G', was measured and used to identify the glass transition temperature $\left(T_{g}\right)$ of neat PET $\left(T_{g P E T}\right)$, neat PC $\left(T_{g P C}\right)$, and the PET domain $\left(T_{g}^{\prime}\right)$ and PC matrix $\left(T_{g}^{\prime \prime}\right)$ in blends. Rectangular torsion geometry was also used for the dynamic frequency sweep tests at temperatures below $200^{\circ} \mathrm{C}$ in the frequency range of $0.01-100 \mathrm{rad} \mathrm{s}^{-1}$. The strain was set in the range of $0.1-0.4 \%$. When the measurement temperature was higher than $200^{\circ} \mathrm{C}$, the parallel plate geometry was used for the dynamic frequency sweep tests at strains of 5-15\%. Prior to the dynamic frequency sweep tests, a strain sweep test was conducted to determine the strain limit for a linear viscoelastic response. A master curve of the G'-frequency was then obtained at $150^{\circ} \mathrm{C}$. To calculate the interfacial tension, the blends were first placed between two parallel plates at $260^{\circ} \mathrm{C}$ for 5 min to completely melt the crystals in the PET domains. The blends then underwent dynamic frequency sweep tests at $250^{\circ} \mathrm{C}$. The blends were confirmed to remain 
1 amorphous during the tests. The extensional viscosity (uniaxial extensional viscosity)

2 was measured with a fixture. Four strain rates, $0.1,0.2,0.5$, and $1.0 \mathrm{~s}^{-1}$, were applied to

3 PC, A0, and $\mathrm{A} 1$ at $240^{\circ} \mathrm{C}$. The testing temperature for sample A5 was set to $220^{\circ} \mathrm{C}$ to

4 prevent the sample from sagging during the measurement. The samples for the

5 rectangular torsion test were approximately $10 \mathrm{~mm}$ in width, $1 \mathrm{~mm}$ in thickness, and 40

$6 \mathrm{~mm}$ in length. The samples for the parallel plate test were $25 \mathrm{~mm}$ in diameter and $2 \mathrm{~mm}$

7 in thickness. The geometry for the samples for the uniaxial elongational viscosity

8 measurement was $18 \mathrm{~mm} \times 10 \mathrm{~mm} \times 0.7 \mathrm{~mm}$. A differential scanning calorimeter (DSC:

9 Pyris 1 Perkin Elmer) was used to measure the crystallinity of the PET domain in the

10 blend polymer and the neat PET. The sample was heated from 40 to $280^{\circ} \mathrm{C}$ at a rate of

$1110^{\circ} \mathrm{C} \mathrm{min}^{-1}$. The crystallinity was calculated using $140 \mathrm{~J} \mathrm{~g}^{-1}$ as the heat of fusion of $100 \%$

12 crystalline PET. [32]

13 With the exception of samples used to measure $T_{g}$ and the interfacial tension, all 14 samples were $\mathrm{CO}_{2}$-annealed at $60^{\circ} \mathrm{C}$ and $10 \mathrm{MPa}$ for $22.3 \mathrm{~h}$ so that the condition of the

15 samples was analogous to that prior to foaming.

16 Characterization of blend and foam morphology

17 Scanning electron microscopy (SEM) was used to observe the blend and cell

18 morphology of the foam. The samples were frozen in liquid nitrogen to create cryogenic

19 fractural surfaces and then coated with gold for $180 \mathrm{~s}$ before observation under a SEM

20 (Tiny-SEM 1540, Technex Co. Ltd., Japan) or field emission SEM (JSM-6700F, Jeol,

21 Japan). FESEM images were collected at an acceleration voltage of $10 \mathrm{kV}$, a current of 5

$22 \mu \mathrm{A}$, and a wide distance of $8 \mathrm{~mm}$. The image processing software Image-J was used to 
1 calculate the dispersed domain density, $N_{d}$, and the number average domain radius, $\overline{R_{d}}$,

2 from the SEM micrographs.

$$
\begin{aligned}
& \overline{R_{d}}=\frac{1}{c} \sum_{i}^{c} R_{i} \\
& N_{d}=\frac{\phi}{\overline{V_{c}}}=\frac{\phi}{\frac{4}{3 c} \pi \sum_{i}^{c} R_{i}^{3}}
\end{aligned}
$$

5 where $R_{i}$ is the radius of the i-th domain measured from the SEM micrographs. $\overline{R_{d}}$ is the

6 average domain radius. $\phi$ is the volume fraction of the dispersed domain, and it is

7 calculated from the weight ratios and densities of both polymers.

9 of blend, $S$, is calculated by:

$$
S=N_{d} \overline{S_{d}}=N_{d} \frac{4}{c} \pi \sum_{i}^{c} R_{i}^{2}
$$

11 where $\overline{S_{d}}$ is the number average domain surface.

13 radius, $\overline{R_{n}}$, were also calculated from the SEM micrographs. The bulk densities of the 14 samples before and after foaming were measured by a densitometer (Mirage Electronic

15 Densimeter MD-200S) and were used to calculate the cell density. The cell density with

16 respect to the solid polymer was then calculated by the following: [33]

$$
N_{f}=\frac{\rho_{s}}{\rho_{f}}\left(\frac{n}{A}\right)^{1.5}
$$


1 where $n$ is the number of bubbles in a total area, $A . \rho_{f}$ and $\rho_{s}$ are the densities of the foam

2 and the solid bulk, respectively. Here, $\rho_{s} / \rho_{f}$ is also known as the foam expansion ratio.

A gas pycnometer (АсcuPyc, Shimadzu Corp.) was used to measure the volume

4 of samples. The volume $\left(V_{\text {mea }}\right)$, excluding the open pores, was measured by the gas

5 pycnometer. The apparent volume of the samples $\left(V_{a p p}\right)$ was measured geometrically

6 using a caliper. Thus, the open-cell content $(\varepsilon)$ and open-cell ratio $\left(\varepsilon_{r}\right)$ were then

7 calculated by the following: [11]

8

9

10

11

12

13

14

15

16

17

18

19

20

$$
\begin{gathered}
\varepsilon=\frac{V_{\text {app }}-V_{\text {mea }}}{V_{\text {app }}} \\
\varepsilon_{r}=\frac{\varepsilon}{1-\rho_{f} / \rho_{s}}
\end{gathered}
$$

The open-cell content $(\varepsilon)$ indicates the volume fraction of open cells in the foam, and the open-cell ratio $\left(\varepsilon_{r}\right)$ indicates the volume ratio of open cells to total (open + closed) cells.

The thickness of the cell wall ( $\delta$ ) was calculated by the following: [2]

$$
\delta=d\left(\frac{1}{\sqrt{1-\rho_{f} / \rho_{s}}}-1\right)
$$

where $d$ is the average cell diameter.

\section{THEORY OF BLEND CHARACTERIZATION IN BRIEF}

\section{Component fraction from the Fox equation}

The $T_{g}$ of a miscible polymer blend can be estimated by the Fox equation. When the equation is applied to partially miscible polymer blends, the minor polymer is commonly assumed to homogeneously infuse the major polymer phase. With this 
1 assumption, we applied the Fox equation to the PET/PC blends to estimate the weight

2 fraction of PET in the PC matrix and that of PC in PET. [34, 35]

$$
\frac{1}{T_{g}^{\prime}}=\frac{\omega_{P E T}^{\prime}}{T_{g P E T}}+\frac{\omega_{P C}^{\prime}}{T_{g P C}}
$$

4 and

$$
\frac{1}{T_{g}^{\prime \prime}}=\frac{\omega_{P E T}^{\prime \prime}}{T_{g P E T}}+\frac{\omega_{P C}^{\prime \prime}}{T_{g P C}}
$$

6 where $\omega_{P C}^{\prime}$ is the weight fraction of PC infused in the PET domain and $\omega_{P E T}^{\prime}\left(:=1-\omega_{P C}^{\prime}\right)$ is

7 the weight fraction of PET in the PET domain. $\omega_{P E T}^{\prime \prime}\left(:=1-\omega_{P C}^{\prime \prime}\right)$ is the weight fraction of

8 PET in the PC matrix, and $\omega_{P C}^{\prime \prime}$ is the PC weight fraction in the PC matrix. $T_{g}^{\prime}$ and $T_{g}^{\prime \prime}$ are

9 the glass transition temperatures of the PET domain and the PC matrix, respectively.

$10 T_{g P E T}$ and $T_{g P C}$ are the glass transition temperatures of the neat PET and the neat PC,

11 respectively.

12 The weight fractions of PC in the PET domain and of PET in the PC matrix were 13 calculated using Eqs. (10) and (11) with the $T_{\mathrm{g}}$ data of the blend and the neat polymers.

$$
\omega_{P C}^{\prime}=\frac{T_{g P C}\left(T_{g P E T}-T_{g}^{\prime}\right)}{T_{g}^{\prime}\left(T_{g P E T}-T_{g P C}\right)} \quad=1-\omega_{P E T}^{\prime}
$$

15 and

$$
\omega_{P E T}^{\prime \prime}=\frac{T_{g P E T}\left(T_{g P C}-T_{g}^{\prime \prime}\right)}{T_{g}^{\prime \prime}\left(T_{g P C}-T_{g P E T}\right)} \quad=1-\omega_{P C}^{\prime \prime}
$$

17 Furthermore, the weight fractions of both the PET domain and the PC matrix could be 18 calculated from mass balance equations, which can be derived by transforming Eqs. (10)19 (11). 


$$
\omega^{\prime}=\frac{\omega_{P C}-\omega_{P C}^{\prime \prime}}{\omega_{P C}^{\prime}-\omega_{P C}^{\prime \prime}}
$$

2 and

$$
\omega^{\prime \prime}=\frac{\omega_{P C}-\omega_{P C}^{\prime}}{\omega_{P C}^{\prime \prime}-\omega_{P C}^{\prime}}
$$

4 where $\omega^{\prime}$ is the estimate of the weight fraction of the PET domain, $\omega^{\prime \prime}$ is the estimate of

5 the weight fraction of the PC matrix in the blend after transesterification reaction and $6 \omega_{P C}$ is the weight fraction (70\% or 90\%) of the PC matrix in the blend before

$7 \quad$ transesterification reaction. [34, 35]

\section{Estimate of interfacial tension}

The storage modulus for the relaxation process, i.e., G' at the secondary plateau,

10 is directly related to the interfacial tension between the dispersed domain and the matrix

11 polymer. [36] The Palierne model was used to calculate the interfacial tension between

12 two polymers. The model relates the dynamic modulus of emulsions with the dynamic

13 modulus of the two phases, the size of the droplets, and the interfacial tension. [37]

14

$$
\begin{gathered}
G^{*}=G_{m}^{*}\left[\left.\frac{1+3 / 2 \sum_{i} \frac{\phi_{i} E_{i}}{D_{i}}}{1-\sum_{i} \frac{\phi_{i} E_{i}}{D_{i}}}\right|_{\rfloor}\right. \\
E_{i}=2\left(G_{d}^{*}-G_{m}^{*}\right)\left(19 G_{d}^{*}+16 G_{m}^{*}\right)+\frac{48 \beta_{d}^{*} \Gamma^{0}}{R_{i}^{2}}+\frac{32 \beta_{s}^{*}\left(\Gamma^{0}+\beta_{d}^{*}\right)}{R_{i}^{2}}+ \\
\frac{8 \Gamma^{0}}{R_{i}}\left(5 G_{d}^{*}+2 G_{m}^{*}\right)+\frac{2 \beta_{d}^{*}}{R_{i}}\left(23 G_{d}^{*}-16 G_{m}^{*}\right)+\frac{4 \beta_{s}^{*}}{R_{i}}\left(13 G_{d}^{*}+8 G_{m}^{*}\right)
\end{gathered}
$$

and 
1

$$
D_{i}=\left(2 G_{d}^{*}+3 G_{m}^{*}\right)\left(19 G_{d}^{*}+16 G_{m}^{*}\right)+\frac{48 \beta_{d}^{*} \Gamma^{0}}{R_{i}^{2}}+\frac{32 \beta_{s}^{*}\left(\Gamma^{0}+\beta_{d}^{*}\right)}{R_{i}^{2}}+
$$

$$
\frac{40 \Gamma^{0}}{R_{i}}\left(G_{d}^{*}+G_{m}^{*}\right)+\frac{2 \beta_{d}^{*}}{R_{i}}\left(23 G_{d}^{*}+32 G_{m}^{*}\right)+\frac{4 \beta_{s}^{*}}{R_{i}}\left(13 G_{d}^{*}+12 G_{m}^{*}\right)
$$

2 where $\Gamma^{0}$ is the interfacial tension. $G_{d}^{*}, G_{m}^{*}$, and $G^{*}$ are the complex moduli of the

3 dispersed domain, matrix, and emulsion (immiscible polymer blend), respectively, over a

4 range of frequencies. $\phi_{i}$ is the volume fraction of a domain with radius $R_{i} . \beta_{d}^{*}$ is the

5 surface dilatation modulus associated with the domain dispersion, and $\beta_{s}^{*}$ is the surface

6 shear modulus attributed to the resistance of the interface to shear deformation. Both

7 complex moduli depend on the frequency.

$8 \quad \beta_{d}^{*}$ is usually associated with the non-uniformity of the interface, and $\beta_{s}^{*}$ is

9 associated with the resistance to shear deformation. We assumed that the interface is

10 uniformly composed of the copolymer such that the surface dilatation modulus, $\beta_{d}^{*}$, can

11 be ignored. However, due to the shear deformation resistance of the copolymer, $\beta_{s}^{*}$

12 should be expressed by the following: [37]

$$
\beta_{s}^{*}=\beta_{s}^{\prime}+\beta_{s}^{\prime \prime}
$$

14 for $\omega \lambda_{\beta}<1$ :

$$
\beta_{s}^{\prime}=\beta_{0}
$$

$$
\beta_{s}^{\prime \prime}=\beta_{0} \omega \lambda_{\beta}
$$

17 for $\omega \lambda_{\beta}>1$ :

$$
\beta_{s}^{\prime}=\beta_{s}^{\prime \prime}=\beta_{0} \sqrt{\omega \lambda_{\beta}}
$$


where $\beta_{0}$ is a low-frequency plateau in the storage modulus for the copolymer and $\lambda_{\beta}$ is

2 a characteristic relaxation time.

$3 \phi_{i}$ and $R_{i}$ were measured from the SEM micrographs of the blend morphology.

$4 G_{d}^{*}$ and $G_{m}^{*}$ were determined by individually measuring the complex moduli of the

5 domain and matrix polymers. $\Gamma^{0}$ and $\beta_{0}$ were then determined by fitting the model

6 estimates of the complex moduli to the experimental data. The detailed procedure for

7 calculating the interfacial tension can be found elsewhere. [37]

9 RESULTS AND DISCUSSION

10 Characterization of blend properties

Figure 1 shows the shear loss moduli (G’) of the PET/PC blends with a 30/70 blend ratio. The $T_{g}$ of the polymer was determined by the temperature at which the G'’-

13 temperature curve reached a peak. [38] The measured $T_{g}$ of the neat PET and PC were $1470.4^{\circ} \mathrm{C}$ and $147.7^{\circ} \mathrm{C}$, respectively. The $T_{g}$ of the PET-dispersed domains in the blend, 15 denoted $T_{g}^{\prime}$, increased from that of neat PET to $79.1^{\circ} \mathrm{C}$. The $T_{g}$ of the PC matrix, $T_{g}^{\prime \prime}$, 16 decreased from that of neat PC to $124.4^{\circ} \mathrm{C}$ by mixing and heat annealing. The miscibility

17 between PET and PC was increased at the interface by the presence of the PET-b-PC 18 copolymer. Therefore, the two $T_{g}$ values approached one another. The copolymer was

19 produced by a transesterification reaction and was characterized by nuclear magnetic 20 resonance (NMR) and Fourier transform infrared spectroscopy (FTIR). [26] The Fox 21 equation was applied by assuming that the PET segment of the copolymer infuses and 22 uniformly disperses into the PC matrix and that the PC segment also infuses into the PET 
1 domain. This equation was then used to estimate the weight fraction of PET that infused

2 the PC matrix and the weight fraction of PC that infused the dispersed PET domains. The

3 calculated weight fractions are listed in Table 2. The details of the calculations are given

4 elsewhere. [35, 39] By conducting the transesterification reaction at $280^{\circ} \mathrm{C}$, the degrees

5 of PET segment infusion into the PC matrix and of PC infusion into the PET-dispersed

6 domains both increased. The weight fractions of the PET domains and PC matrix were

7 obtained from Eqs. (12) and (13) and used to calculate the crystallinity of the PET

8 domains, domain density, and interfacial area between the PET domains and the PC

9 matrix.

Figure 2 shows the SEM micrographs of the PET/PC blend with a 30/70 blend

11 ratio. A sea-island morphology was observed in most of the blends. The dispersed

12 domains consisted of PET, whereas the matrix consisted of PC. The domain size

13 decreased as the heat-annealing time increased for the blend with a 30/70 PET/PC blend

14 ratio. The rheological data of the blends indicates that a longer heat-annealing time could

15 produce more copolymer and increase the miscibility between the PET domains and the

16 PC matrix. Consequently, the diameter of the domains decreased.

The domain size was measured and used to calculate the interfacial tension. The

18 values of the interfacial tension are given in Table 3 . The interfacial tension was

19 determined by fitting the Palierne model to the experimental data of the storage and loss

20 moduli. Figure 3 shows the experimental data and the model estimates for the PET/PC

21 blends with a 30/70 blend ratio. The validity of the Palierne model was confirmed in our

22 previous study on Poly(methyl methacrylate) (PMMA)/PC and PMMA/PP blends. [25]

23 The model also agreed well with the experimental data for the PET/PC blends. The non- 
1 heat-annealed PET/PC blend, A0, exhibited the largest interfacial tension, $2.3 \mathrm{mN} \mathrm{m}^{-1}$,

2 and blends $\mathrm{A} 5$ and $\mathrm{B} 5$ showed the smallest interfacial tensions, less than $0.01 \mathrm{mN} \mathrm{m}^{-1}$.

3 The interfacial tension inversely correlated with the heat-annealing time in both the 30/70

4 and 10/90 blends.

5 The domain diameter, $2 \times \overline{R_{d}}$, the domain density, $N_{d}$, and the interfacial area per

6 unit blend volume, $S$, were measured from SEM micrographs and calculated using Eqs.

7 (1)-(3). The calculated values were plotted as a function of the interfacial tension, as

8 shown in Figure 4. For PET/PC with a blend ratio of 30/70 (i.e., the A series), the size of

9 the PET dispersed domains decreased from approximately $1.2 \mu \mathrm{m}$ to $400 \mathrm{~nm}$, the domain

10 density and the interfacial area per unit volume of polymer blend increased as a result of

11 the decreasing interfacial tension. In other words, the compatibility, uniformity and

12 dispersion of the PET domains in the blend were drastically improved by increasing the

13 copolymer, i.e., increasing the heat-annealing time. In contrast, the PET domain size was

$14300 \mathrm{~nm}$ without heat annealing for PET/PC with a blend ratio of 10/90 (i.e., B0), and it

15 did not change with the decrease in interfacial tension, as shown in Figure 4-a.

16 Furthermore, the domain density and the interfacial area per unit volume of the polymer

17 blend showed results opposite to those of the PET/PC blend with a 30/70 blend ratio

18 (Figure 4-b and c): the domain density and interfacial area both decreased when the

19 interfacial tension decreased. Because of the low volume fraction of PET in the 10/90

20 wt\% PET/PC blends (Table 2), the PET domains could be well dispersed without heat

21 annealing. The amount of copolymer correlated positively with the heat annealing time.

22 However, increasing the amount of copolymer enhanced the infusion of PET segments

23 into the PC matrix rather than improving the PET domain dispersion and uniformity in 
1 the blend. As the heat-annealing time increased and the interfacial tension decreased, the

2 small PET domains tended to disappear because PET was transformed into the copolymer,

3 which was infused into the PC matrix. Therefore, both the PET domain density and the

4 interfacial area per unit volume of the blend polymer decreased in the 10/90 wt\% PET/PC

5 blends as the interfacial tension decreased.

Figure 5 shows the DSC curves of the neat PET and PET/PC blends with a 30/70 wt $\%$ blend ratio annealed under $10 \mathrm{MPa}-\mathrm{CO}_{2}$ at $60^{\circ} \mathrm{C}$ for $22.3 \mathrm{~h}$. The thermal properties measured by DSC are summarized in Table 4 . The PET crystallized even though the

$9 \mathrm{CO}_{2}$-annealing temperature for $\mathrm{A} 0, \mathrm{~A} 1$, and $\mathrm{A} 5$ was lower than the glass transition temperatures of the neat PET and the PET phase in the blends. This crystallization can be

11 attributed to the plasticization effect of $\mathrm{CO}_{2}$. Two peaks were detected in both the neat

12 PET and blends (A0, A1). When the neat PET and its blends were $\mathrm{CO}_{2}$-annealed, a

13 secondary crystallization occurred, which was detected by the peak of the heat curve at

14 approximately $110^{\circ} \mathrm{C}$. The peaks of the secondary and primary crystals were, respectively

15 denoted $T_{m 2}$ and $T_{m 3}$ in Figure 5. As shown in Table 4, the enthalpy of fusion of the

16 primary crystals, $\Delta H_{3}$, decreased as the amount of copolymer increased; $T_{m 2}$ could not be

17 clearly detected in blends A5 because it overlapped with the glass transition temperature

18 of PC: the melting point of the secondary crystals, $T_{m 2}$, increased while that of the

19 primary crystals, $T_{m 3}$, decreased as the amount of copolymer increased. This relationship

20 indicates that the crystalline structures of the primary crystals thinned and became less

21 perfect while those of the secondary crystals thickened as the amount of copolymer

22 increased. The melting points of the primary and secondary crystals often move in

23 opposite directions. [40] 
The crystallization of the polymers is also affected by the size of the dispersed domain. [41] Tol et al. reported a homogeneous nucleation process for a Polystyrene (PS)/Styrene-maleic anhydride (SMA)/Polyamide (PA6) blend in submicron dispersed PA6 domains. The imperfect crystals had a very low melting temperature compared with the primary and secondary crystals. In samples A5, B0, B1 and B5, the dispersed PET

6 domain size was less than 500 nm (Figure 4-a). Therefore, the nucleation induced in the PET domains tended to be homogeneous because the size was too small for crystals to exist. The corresponding peak was then denoted $T_{m 1}$, as shown in the enlarged section in Figure 5. The total crystallinity was calculated from the enthalpy of the primary crystals $\left(\Delta H_{3}\right)$, the enthalpy of the secondary crystals $\left(\Delta H_{2}\right)$ and the enthalpy of the crystals

11 induced by the homogeneous nucleation in the submicron dispersed PET domains $\left(\Delta H_{1}\right)$.

12 The total crystallinity decreased from $29 \%$ to $7.8 \%$ in the $30 / 70$ blend ratio PET/PC and 13 from $26 \%$ to $9.4 \%$ in the $10 / 90$ blend ratio PET/PC.

The master curves of the PC and PET/PC blends with a 30/70 wt\% blend ratio are

15 shown in Figure 6. The viscoelastic modulus of all samples originated in the glassy zone $16\left(\mathrm{G}^{\prime}>10^{8} \mathrm{~Pa}\right)$, moved from the transition zone to the plateau zone $\left(10^{7} \mathrm{~Pa}>\mathrm{G}^{\prime}>10^{6} \mathrm{~Pa}\right)$ and

17 finally reached the terminal zone $\left(\mathrm{G}^{\prime}<10^{5} \mathrm{~Pa}\right)$. When the samples were foamed at either 1880,120 and $150^{\circ} \mathrm{C}$, they were mostly in the rubbery state, in which the polymer chains 19 could move to create voids and the elasticity of the polymer matrix could still maintain its 20 shape. As shown in Figure 6, the elasticity of PC was higher than that of the PET/PC 21 blends over the entire frequency range. As the heat-annealing time increased, the amount 22 of the PET segments that infused the PC matrix increased and the elasticity of the 
1 PET/PC blends decreased. Furthermore, the $T_{g}$ of PC decreased, along with the elasticity

2 and viscosity of the PC matrix.

Figure 7 shows the uniaxial extensional viscosity of the PC and the PET/PC blends (A0, A1, and A5). The viscosity measurements were conducted at four different constant strain rates, $0.1,0.2,0.5$, and $1.0 \mathrm{~s}^{-1}$, at $240^{\circ} \mathrm{C}$ for all samples, except for blend A5. Blend A5 was measured at $220^{\circ} \mathrm{C}$ to prevent it from sagging during the measurement.

$7 \quad$ None of the samples showed any strain hardening behavior.

8 Cell morphology of foamed blends were foamed at three different temperatures, 80,120 , and $150^{\circ} \mathrm{C}$. Under these foaming

11 conditions, bubble nucleation occurred only in PC and not in the PET domain due to the

12 presence of crystals. However, the PET domains could serve as the bubble nucleating 13 agents. Figures 8 and 9 show the SEM micrographs of the foamed PET/PC blends (A014 A5) and (B0-B5), respectively. The higher magnification SEM micrographs are also

15 shown in Figures 10 and 11. All foams showed a spherical cell geometry. As the foaming temperature increased, the cells impinged on each other and the cell wall thickness was

17 reduced. The higher magnification SEM images in Figures 10 and 11 show that the foam

18 of blend A0, which had the largest interfacial tension, showed smooth cell walls. The

19 PET domain seems to function as a bubble nucleating agent, and bubble nucleation

20 occurred at the weak interface between the PET and PC. The foams of blend A1 and B0,

21 which had the reduced interfacial tension and PET crystallinity, showed a fibril-like

22 structure around the PET domains. The lowered interfacial tension and the infusion of

23 copolymer into PET and PC increased the bonding force between PET and PC. The 
1 bonding force then stretched the crystal lamellas in the PET domains to form the fibril-

2 like structure. Further increasing the heat-annealing further decreased the interfacial

3 tension. Moreover, the crystallinity of the PET domains also decreased. Therefore, the

4 degree of fibrillation decreased, as shown in the micrograph of foamed blends A5, B1,

5 and B5. Therefore, blends A1 and B0 showed a higher degree of fibrillation than blends

6 A5, B1, and B5, in which the PET domains had a much lower crystallinity. These

7 findings indicated that the fibril-like structure was generated by stretching the crystalline

8 lamellas in the PET domains in the presence of bonding forces between PET and PC.

$9 \quad$ The cell density and the cell size were measured from the SEM micrograph, and

10 the results are illustrated in Figure 12. The cell density of blends A0, A5, B1, and B5

11 decreased as the foaming temperature increased, as shown in Figure 12. Only blends A1

12 and B0, which showed a highly fibrillar cell morphology, showed an increase in the cell

13 density as the foaming temperature increased. A higher foaming temperature led to a

14 larger degree of supersaturation and increased the cell density per unit volume of the

15 solid polymer. The decreased cell density for blends A0, A5, B1, and B5 could be

16 attributed to cell coalescence that resulted from a decrease in the viscosity at high

17 foaming temperatures. The increase in the cell density for blends A1 and B0 was not

18 induced by the suppression of cell coalescence because neither blend showed strain

19 hardening behavior. However, this increase could be related to the formation of fibril-like

20 structures. The bubble nucleation mechanism in blends A1 and B0 could likely differ

21 from that of blends A0, A5, B1, and B5. This difference might be related to the stretch-

22 induced void formation in crystalline polymers. 
2 foamed samples was measured. The open-cell ratio (volume ratio of open cells to total

3 cells) and cell wall thickness were then calculated using Eqs. (6) and (7). The results are

4 presented in Figures 13 and 14. Increasing the foaming temperature increased the

5 expansion ratio. This increase, in turn, increased the open-cell content of most of the

6 foams. Nevertheless, blends A1 and A5 shrank when they were foamed at $150^{\circ} \mathrm{C}$ because

7 the foaming temperature was much higher than the glass transition temperature of the

8 matrix polymer PC. Thus, their expansion ratio was not increased with the increase in the

9 foaming temperature, which also prevented the open-cell content from increasing. Figure

1014 also shows that the open-cell ratio increased monotonously as the cell walls thinned.

11 The PET/PC 10/90 wt\% blend performed better overall with respect to the cell density,

12 cell size and open-cell content. The fibril-structure of blend B0 could provide the high

13 open-cell content with the low expansion ratio.

\section{CONCLUSIONS}

In this study, we reported a novel method for controlling the foam morphology of

17 open-cell foams by forming fibril-like structures around the PET domains. Heat 18 annealing was a critical process for modifying the interfacial properties by forming a 19 copolymer at the interface between the PET and PC phases. The interfacial tension 20 decreased, the affinity between PET and PC increased, and the crystallinity of the PET 21 domains decreased as the amount of copolymer increased. When the interfacial affinity 22 was strong, a fibril-like structure formed during $\mathrm{CO}_{2}$ foaming by stretching the crystalline 23 lamellas in the PET domains. The degree of fibrillation was a function of the crystallinity 
1 of the PET domains. When the heat-annealing procedure was optimized to generate a

2 large degree of fibrillation during $\mathrm{CO}_{2}$ foaming, PET/PC blend foams with a large cell

3 density $\left(7 \times 10^{11} \# \mathrm{~cm}^{-3}\right)$, a small cell size (less than $\left.2 \mu \mathrm{m}\right)$, and $100 \%$ open cells were

4 generated.

6 REFERENCES

7 1. H. Ruckdaschel, P. Gutmann, V. Altstadt, H. Schmalz, A.H.E. Muller, Adv. Polym.

8 Sci., 227, 199 (2010).

9 2. D. Klempner, K.C. Frisch, Handbook of Polymeric Foams and Foam Technology,

$10 \quad$ New York (1991).

11 3. M. Mantovani, C. Gastagnetti, P.P. Godano, H. Yamaguchi, Japan Patent, 4279,624

12 (2005).

13 4. D.T. Wong, S.A. Mullin, V.S. Battaglia, N.P. Balsara, J. Membr. Sci., 394-395, 175

14 (2012).

15 5. X. Liao, H. Zhang, T. He, J. Nanomater., 1 (2012).

16 6. P.C. Lee, G. Li, J.W.S. Lee, C.B. Park, J. Cell. Plast., 43, 431 (2007).

17 7. P.C. Lee, H.E. Naguib, C.B. Park, J. Wang, Polym. Eng. Sci., 45, 1445 (2005).

18 8. D. Kohlhoff, M. Ohshima, Macromol. Mater. Eng., 296, 770 (2011).

19 9. P.C. Lee, J. Wang, C.B. Park, Ind. Eng. Chem. Res., 45, 175 (2006).

20 10. C.B. Park, V. Padareva, P.C. Lee, H.E. Naguib, J. Polym. Eng., 25, 239 (2005).

21 11. R. Miyamoto, M. Fukumori, H. Shikuma, M. Ohshima, Proceeding of the Polymer

22 Processing Society 28th Annual Meeting (PPS-28), Pattaya in Thailand (2012). 
1 12. B. Krause, M.E. Boerrigter, N.F.A. van der Vegt, H. Strathmann, M. Wessling, J.

2 Membr. Sci., 187, 181 (2001).

3 13. B. Krause, H.J.P. Sijbesma, P. Münüklü, N.F.A. van der Vegt, M. Wessling,

$4 \quad$ Macromolecules, 34, 8792 (2001).

5 14. B. Krause, K. Diekmann, N.F.A. van der Vegt, M. Wessling, Macromolecules, 35, $61738(2002)$.

7 15. Y. Li, Z. Yao, Z. Chen, K. Cao, S. Qiu, F. Zhu, C. Zeng, Z. Huang, Chem. Eng. Sci., $8 \quad$ 66, $3656(2011)$.

9 16. W. Zhai, H. Wang, J. Yu, J. Dong, J. He, Polym. Eng. Sci., 48, 1312 (2008).

10 17. Q. Liao, A. Tsui, S. Billington, C.W. Frank, Polym. Eng. Sci., 52, 1495 (2012).

11 18. W. Zhai, J. Wang, N. Chen, H.E. Naguib, C.B. Park, Polym. Eng. Sci., 52, 2078 12 (2012).

13 19. C.A. Kumar, J. Krishnamurthy, Polym. Eng. Sci., 51, 1749 (2011).

14 20. P. Spitael, C.W. Macosko, Polym. Eng. Sci., 44, 2090 (2004).

15 21. P. Spitael, C.W. Macosko, R.B. McClurg, Macromolecules, 37, 6874 (2004).

16 22. R.W. Sharudin, A. Nabil, K. Taki, M. Ohshima, J. Appl. Polym. Sci., 119, 1042 17 (2010).

18 23. W. Zhai, H. Wang, J. Yu, J. Dong, J. He, J. Polym. Sci. Part B: Polym. Phys., 46, $191641(2008)$.

20 24. S. Siripurapu, J.M. DeSimone, S.A. Khan, R.J. Spontak, Macromolecules, 28, 2271 21 (2005).

22 25. P. Gong, M. Ohshima, J. Appl. Polym. Sci., Accepted.

23 26. P. Gong, M. Ohshima, J. Polym. Sci. Part B: Polym. Phys., 50, 1173 (2012). 
1 27. T.R. Nassar, D.R. Paul, J.W. Barlow, J. Appl. Polym. Sci., 23, 85 (1979).

2 28. D. Ma, G. Zhang, Y. He, J. Ma, X. Luo, J. Polym. Sci. Part B: Polym. Phys., 37, 2960

3 (1999).

4 29. T. Suzuki, H. Tanaka, T. Nishi, Polymer, 30, 1287 (1989).

$5 \quad$ 30. Z. Zhang, Y. Xie, D. Ma, Eur. Polym. J., 37, 1961 (2001).

6 31. M. Fiorini, F. Pilati, C. Berti, M. Toselli, V. Ignatov, Polymer, 38, 413 (1997).

7 32. P. Gong, T. Liu, L. Zhao, J. Macromol. Sci. Part B: Phys., 50, 329 (2011).

$8 \quad$ 33. C.B. Park, P.C. Lee, J. Wang, V. Padareva, Cell. Polym., 25, 1 (2006).

9 34. R.S. Porter, L.H. Wang, Polymer, 33, 2019 (1992).

10 35. N. Marin, B.D. Favis, Polymer, 43, 4723 (2002).

11 36. D. Graebling, R. Muller, J.F. Palierne, Macromolecules, 26, 320 (1993).

12 37. H. Asthana, K. Jayaraman, Macromolecules, 32, 3412 (1999).

13 38. The Society of Polymer Science, Kisokoubunnshikagaku, Tokyo (2006).

14 39. W.N. Kim, C.M. Burns, Macromolecules, 20, 1876 (1987).

15 40. Z.G. Wang, B.S. Hsiao, B.B. Sauer, W.G. Kampert, Polymer, 40, 4615 (1999).

16 41. R.T. Tol, V.B.F. Mathot, G. Groeninckx, Polymer, 46, 2955 (2005). 


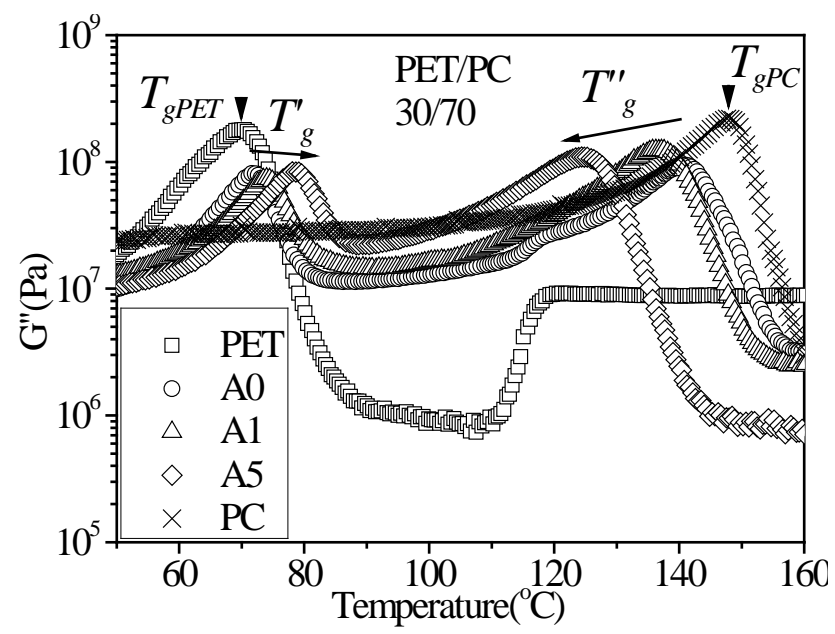

3 Figure 1 Shear loss moduli (G’') of PET, PC, and 30/70 wt\% PET/PC blends (A0, A1, 4 and A5) 


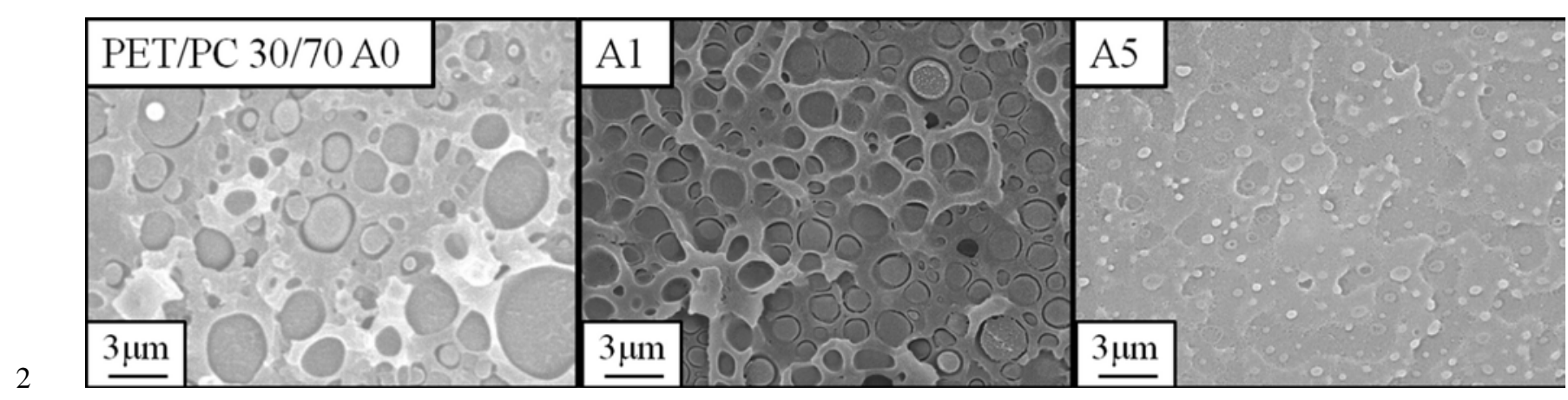

3 Figure 2 SEM morphology of the 30/70 wt\% (A0, A1, and A5) PET/PC blends 


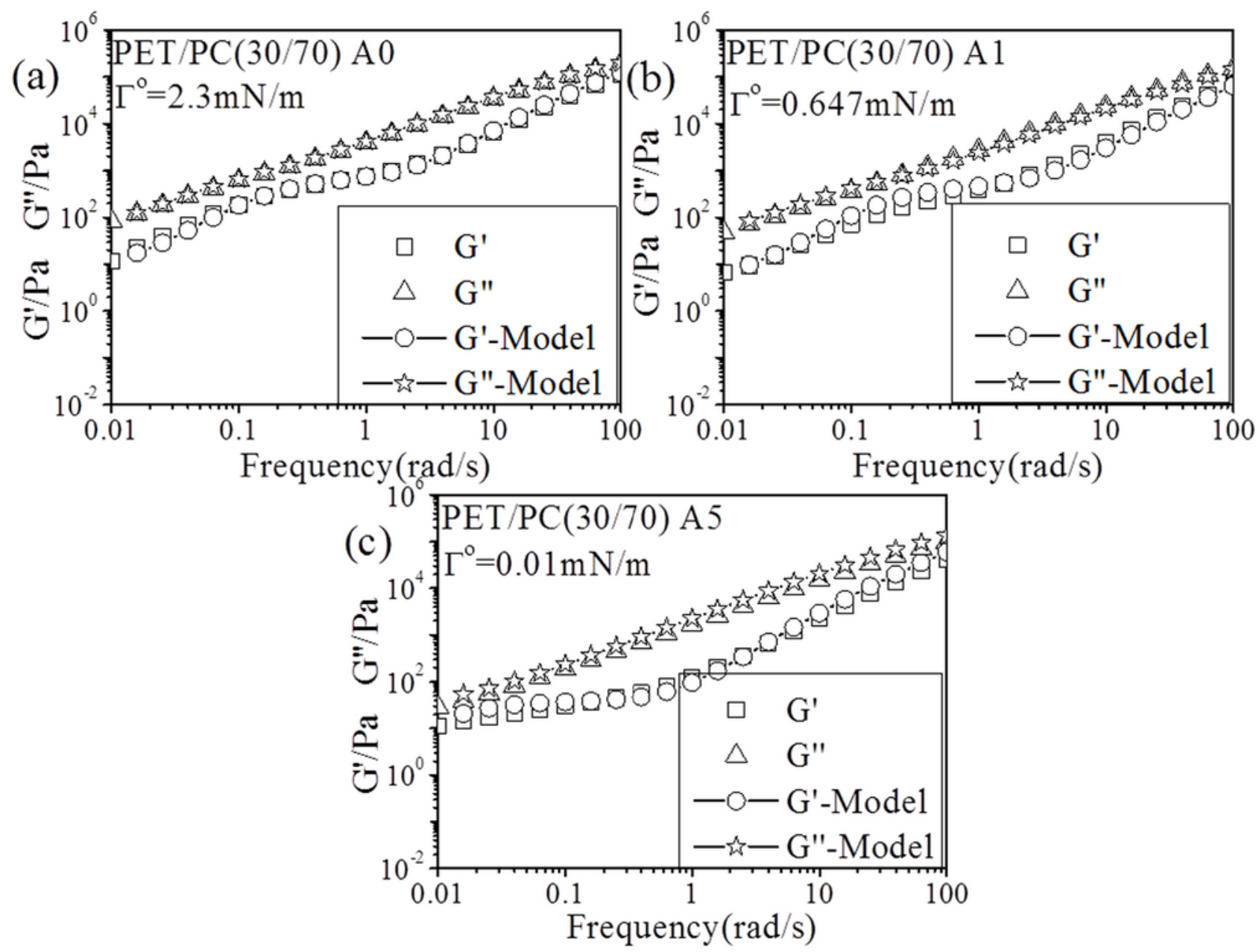

Figure 3 Estimates of the Palierne model and experimental data of the dynamic modulus 

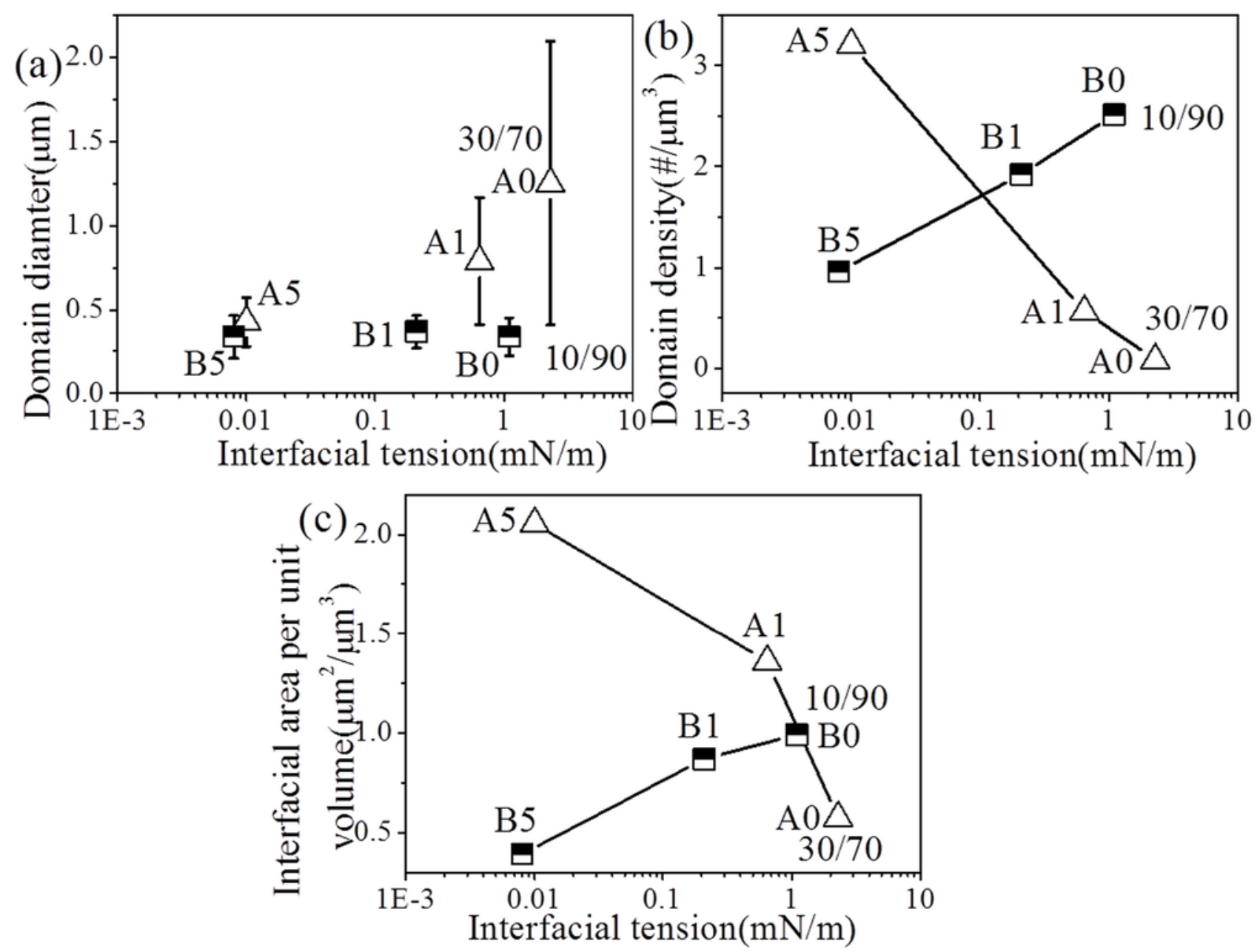

3 Figure 4 Number average domain diameter, $2 \times \overline{R_{d}}$ (a), the dispersed domain density, $N_{d}$

4 (b), and the interfacial area per unit blend volume, $S$ (c) of the PET/PC blends 


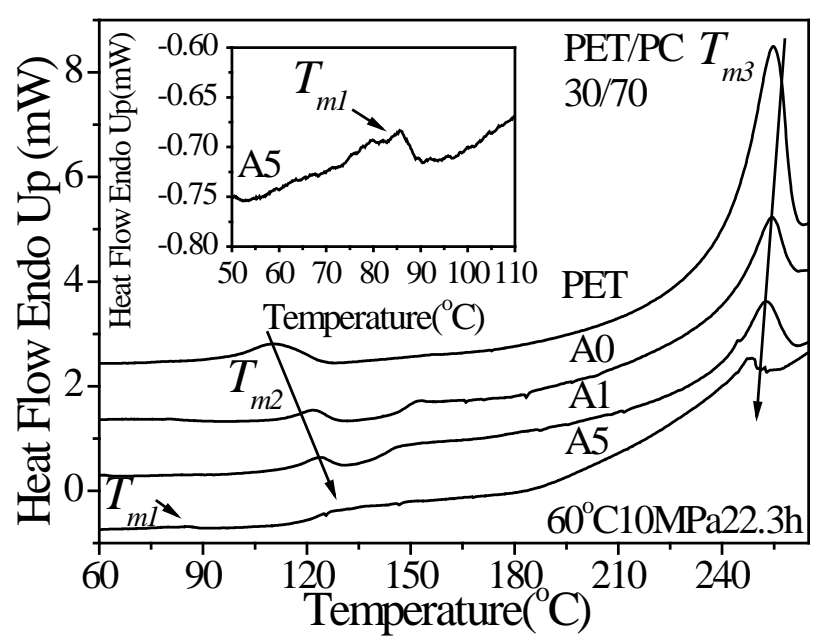

2

3 Figure 5 DSC heat curves of the neat PET and the PET/PC 30/70 wt\% blends (A0, A1,

4 and $\mathrm{A} 5$ ) after $\mathrm{CO}_{2}$-annealing at $60^{\circ} \mathrm{C} 10 \mathrm{MPa}$ for $22.3 \mathrm{~h}$

5 


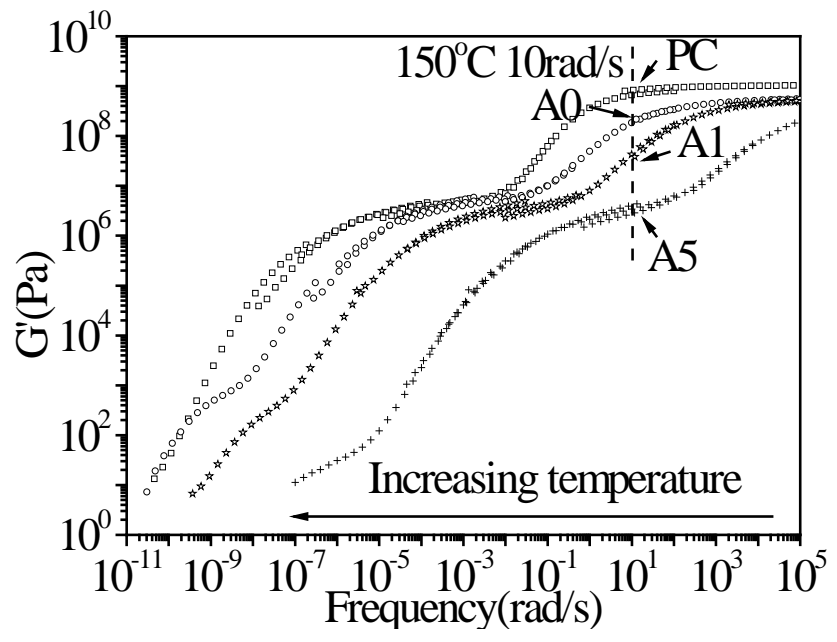

3 Figure 6 Master curves of the G' of PC and PET/PC 30/70 wt\% blends (A0, A1, and A5)

4 at $150^{\circ} \mathrm{C}$ 

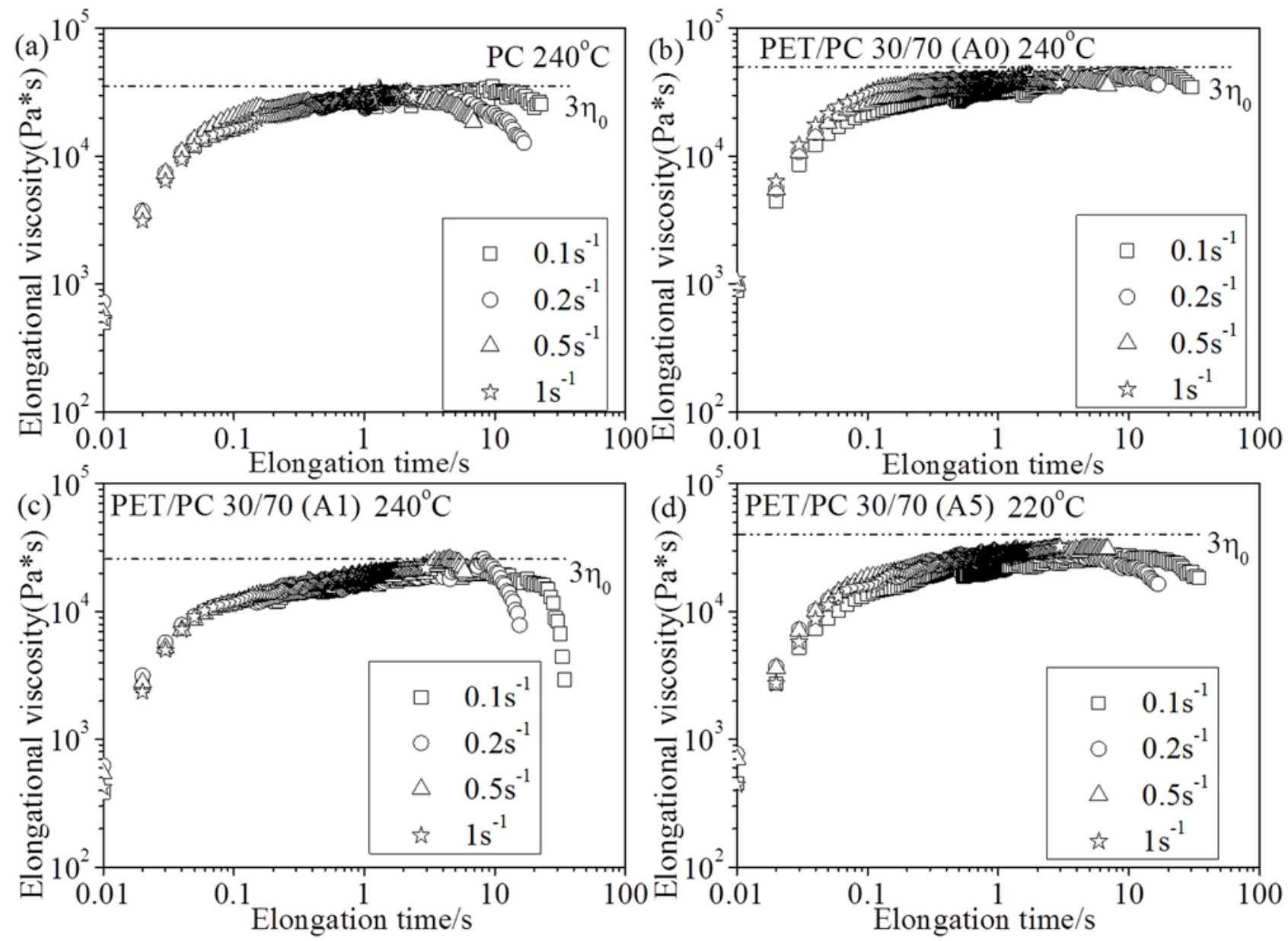

3 Figure 7 Uniaxial elongational viscosity of PC and PET/PC 30/70 wt\% blends (A0, A1)

4 at $240^{\circ} \mathrm{C}$ and the $\mathrm{PET} / \mathrm{PC} 30 / 70 \mathrm{wt} \%$ blend (A5) at $220^{\circ} \mathrm{C}$ at different constant strain rates. Dashed lines represent the value of three times the zero shear viscosity 


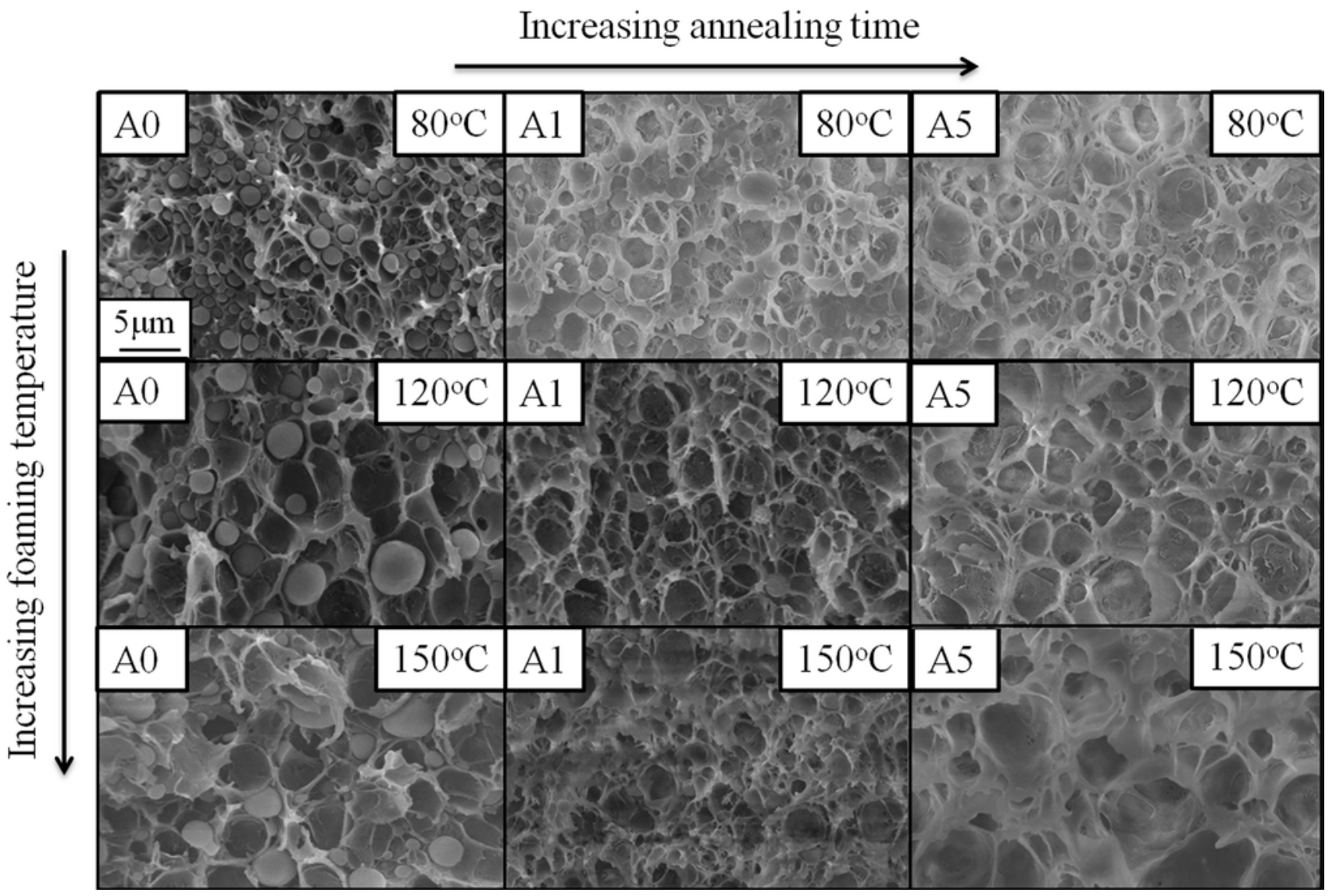

Figure 8 SEM micrographs of PET/PC 30/70 wt\% blends (A0, A1, and A5) foamed at 80, 


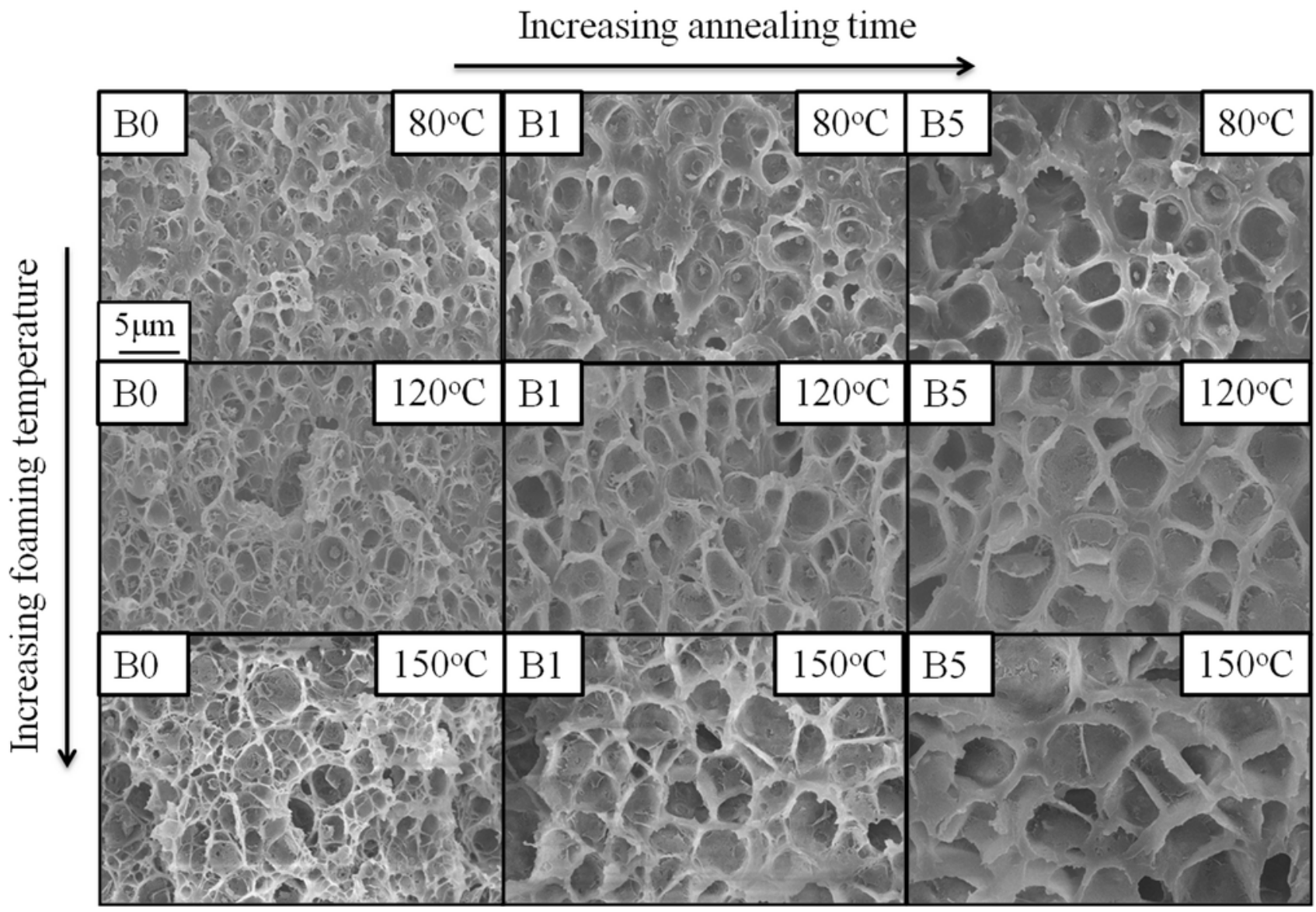

3 Figure 9 SEM micrographs of PET/PC 10/90 wt\% blends (B0, B1, and B5) foamed at 80,

$4 \quad 120$, and $150^{\circ} \mathrm{C}($ Magnification $\times 3000)$ 


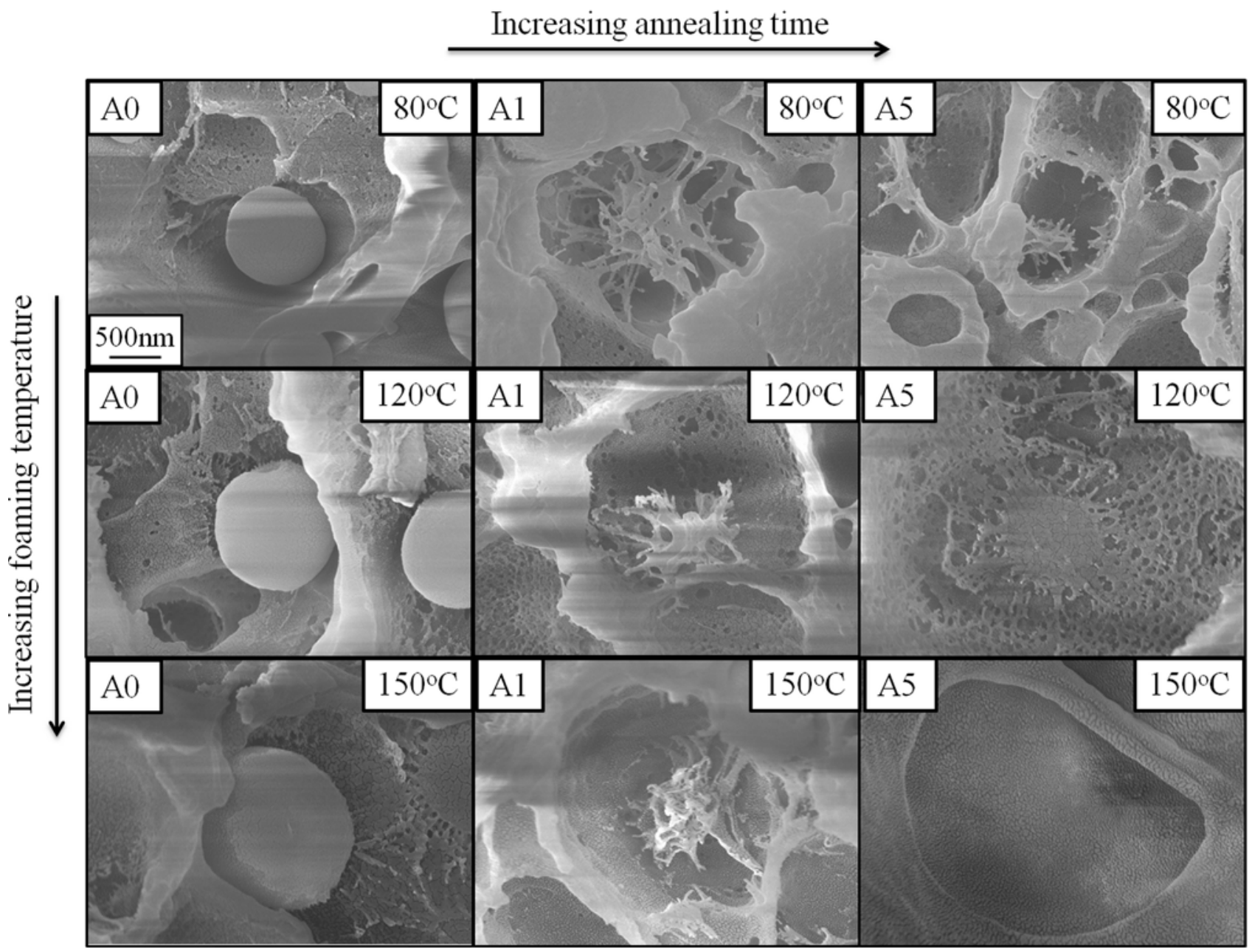

3 Figure 10 SEM micrographs of PET/PC 30/70 wt\% blends (A0, A1, and A5) foamed at

$4 \quad 80,120$, and $150^{\circ} \mathrm{C}$ (Magnification $\left.\times 30000\right)$ 


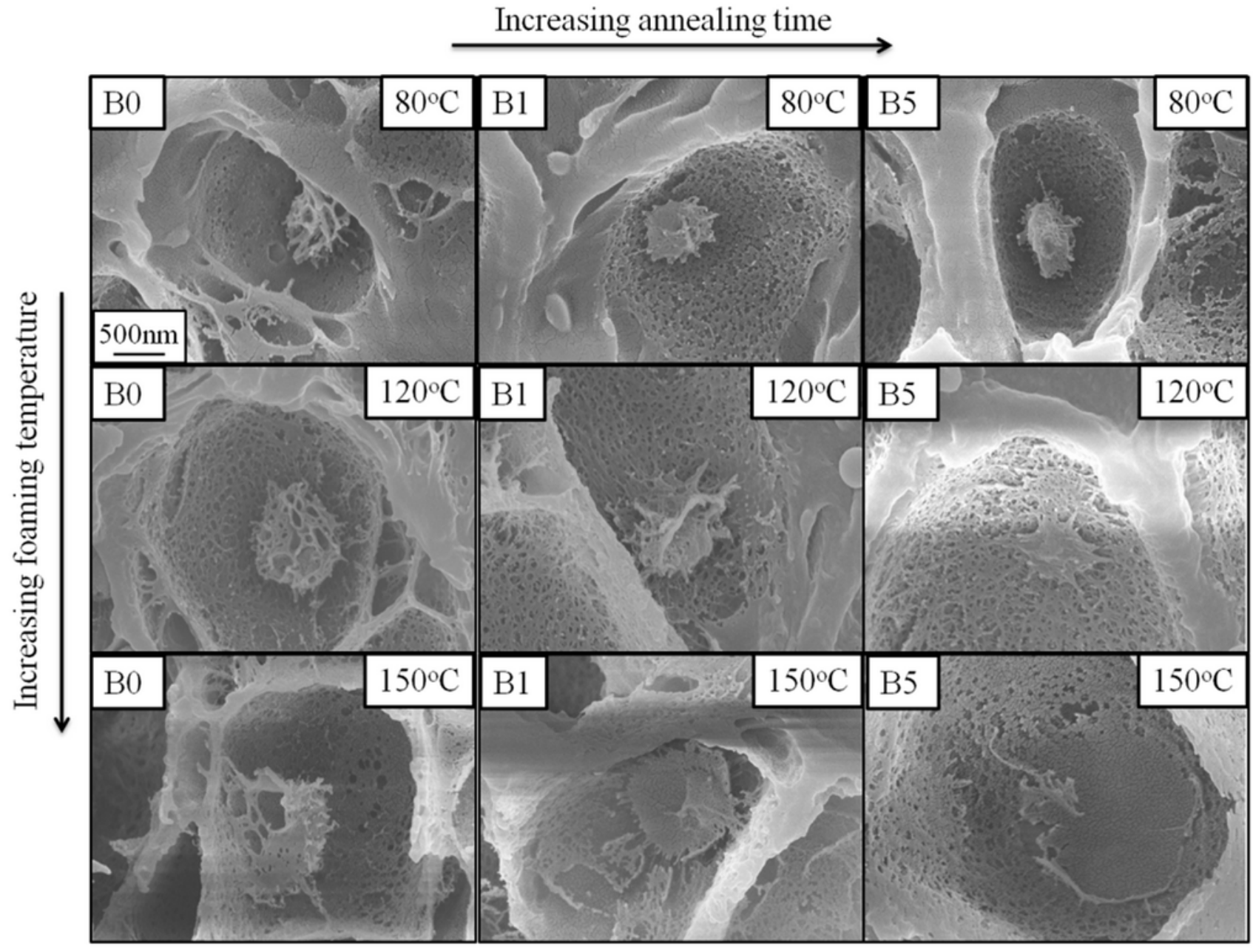

Figure 11 SEM micrographs of PET/PC 10/90 wt\% blends (B0, B1, and B5) foamed at 

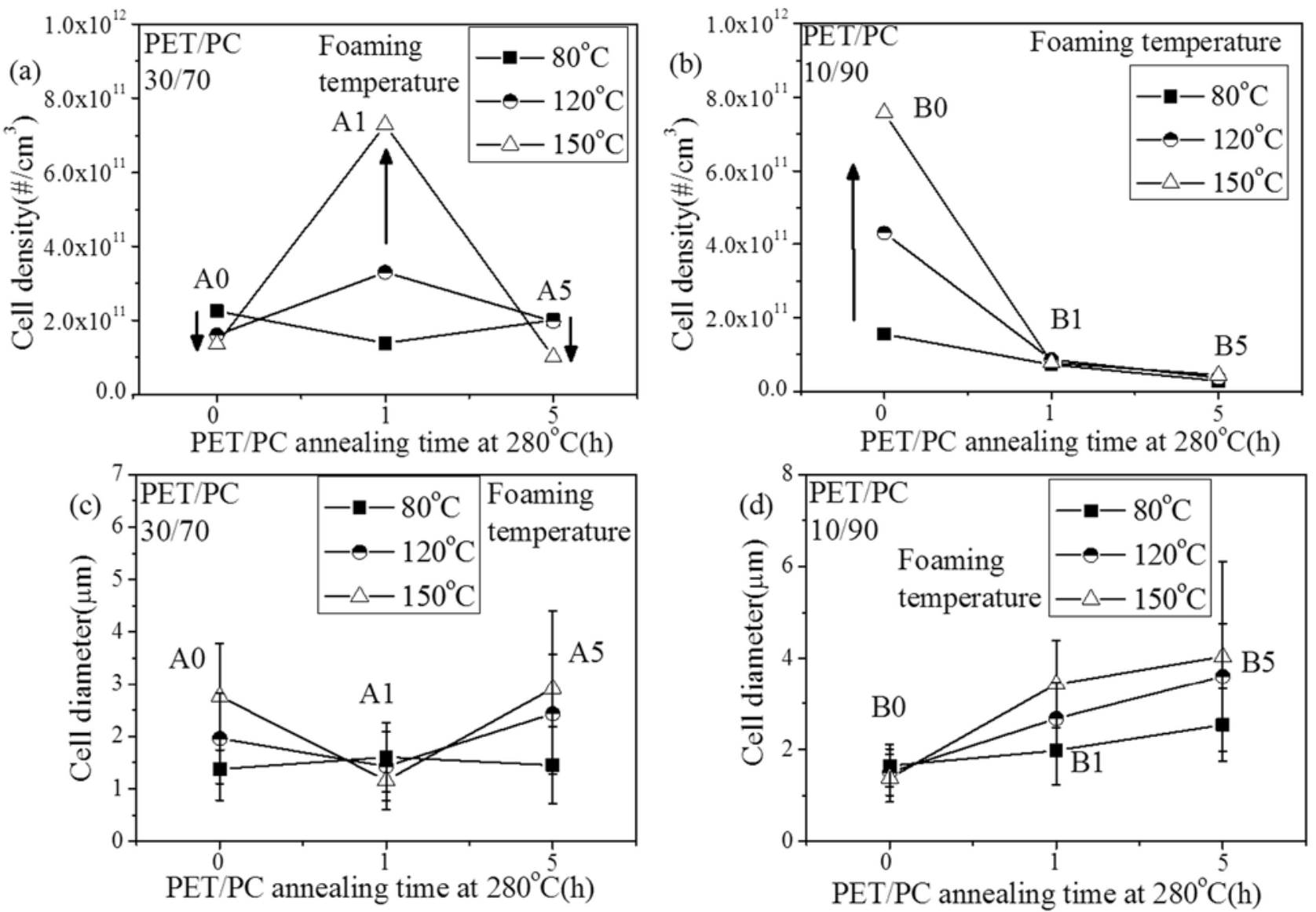

3 Figure 12 Cell density, (a) and (b), and cell size, (c) and (d), of the blends foamed at 80, $4 \quad 120$, and $150^{\circ} \mathrm{C}$ 

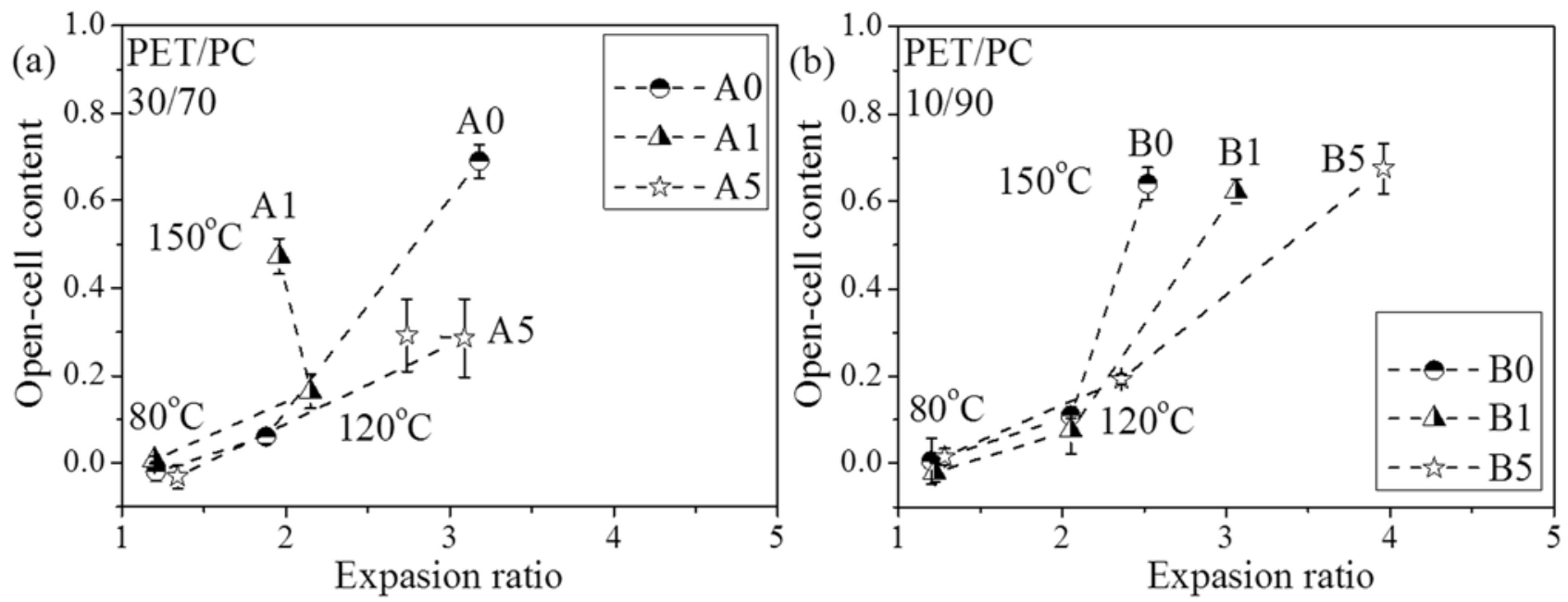

Figure 13 Open-cell content of PET/PC 30/70 wt\% (a) and PET/PC 10/90 wt\% (b) blends

as a function of expansion ratio 


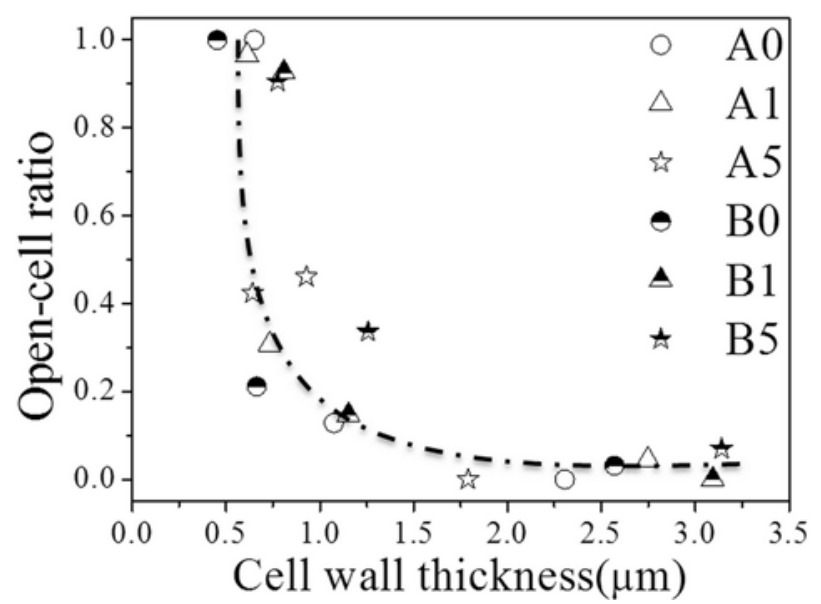

3 Figure 14 Open-cell ratio as a function of cell wall thickness 
2 Table 1 Weight ratio, heat-annealing time, and sample ID. of PET/PC blends

\begin{tabular}{ccc}
\hline Blend ratio & Heat-annealing time & Sample ID. \\
\hline \multirow{2}{*}{ PET/PC } & $0 \mathrm{~h}$ & $\mathrm{~A} 0$ \\
$\mathbf{3 0} / \mathbf{7 0}$ & $1 \mathrm{~h}$ & $\mathrm{~A} 1$ \\
& $5 \mathrm{~h}$ & $\mathrm{~A} 5$ \\
\hline \multirow{2}{*}{ PET/PC } & $0 \mathrm{~h}$ & $\mathrm{~B} 0$ \\
$\mathbf{1 0} / \mathbf{9 0}$ & $1 \mathrm{~h}$ & $\mathrm{~B} 1$ \\
& $5 \mathrm{~h}$ & $\mathrm{~B} 5$ \\
\hline
\end{tabular}

3

4 
2 Table $2 T_{g}$ and the estimated weight percentages of PET and PC in the PET domain and

3 PC matrix of the PET/PC blends

\begin{tabular}{cc|cccc|cccc}
\hline \multirow{2}{*}{ PET/PC } & \multicolumn{5}{|c|}{ PET domain } & \multicolumn{4}{c}{ PC matrix } \\
& & $T_{g}^{\prime}\left({ }^{\circ} \mathrm{C}\right)$ & $\omega_{P E T}^{\prime}$ & $\omega_{P C}^{\prime}$ & $\omega^{\prime}$ & $T_{g}^{\prime \prime}\left({ }^{\circ} \mathrm{C}\right)$ & $\omega_{P E T}^{\prime \prime}$ & $\omega_{P C}^{\prime \prime}$ & $\omega^{\prime \prime}$ \\
\hline \multirow{2}{*}{$\mathbf{3 0 / 7 0}$} & $\mathbf{A 0}$ & 71.7 & $96.7 \%$ & $3.3 \%$ & $27.5 \%$ & 140.5 & $4.6 \%$ & $95.4 \%$ & $72.5 \%$ \\
& $\mathbf{A 1}$ & 74.0 & $90.9 \%$ & $9.1 \%$ & $26.9 \%$ & 136.3 & $7.6 \%$ & $92.4 \%$ & $73.1 \%$ \\
& A5 & 79.1 & $79.0 \%$ & $21.0 \%$ & $20.8 \%$ & 124.4 & $17.1 \%$ & $82.9 \%$ & $79.2 \%$ \\
\hline \multirow{2}{*}{$\mathbf{1 0 / 9 0}$} & $\mathbf{B 0}$ & 72.5 & $94.6 \%$ & $5.4 \%$ & $8.0 \%$ & 143.6 & $2.6 \%$ & $97.4 \%$ & $92.0 \%$ \\
& $\mathbf{B 1}$ & 73.9 & $91.1 \%$ & $8.9 \%$ & $7.1 \%$ & 141.8 & $3.8 \%$ & $96.2 \%$ & $92.9 \%$ \\
& $\mathbf{B 5}$ & 75.9 & $86.2 \%$ & $13.8 \%$ & $3.3 \%$ & 136.6 & $7.4 \%$ & $92.6 \%$ & $96.7 \%$ \\
\hline
\end{tabular}

4 
2 Table 3 Interfacial tension calculated using the Palierne model

\begin{tabular}{cc|c}
\hline \multicolumn{2}{c|}{ Blend component } & \multicolumn{2}{c}{ Interfacial tension (mN/m) } \\
\hline \multirow{2}{*}{ PET/PC } & A0 & 2.3 \\
30/70 & A1 & 0.647 \\
& A5 & 0.01 \\
\hline \multirow{2}{*}{ PET/PC } & B0 & 1.1 \\
10/90 & 1 & 0.21 \\
& B5 & 0.008 \\
\hline
\end{tabular}

3

4 
2 Table 4 Thermal properties of the neat PET and PET/PC blends after $\mathrm{CO}_{2}$-annealing at

$3 \quad 60^{\circ} \mathrm{C} 10 \mathrm{MPa}$ for $22.3 \mathrm{~h}$

\begin{tabular}{|c|c|c|c|c|c|c|c|c|}
\hline Sample ID. & $T_{\mathrm{m} 1}\left({ }^{\circ} \mathrm{C}\right)$ & $\Delta H_{1}(\mathrm{~J} / \mathrm{g})$ & $T_{\mathrm{m} 2}\left({ }^{\circ} \mathrm{C}\right)$ & $\mathrm{H}_{2}(\mathrm{~J} / \mathrm{g})$ & $\mathbf{T}_{\mathrm{m} 3}\left({ }^{\circ} \mathbf{C}\right)$ & $\mathrm{H}_{3}(\mathrm{~J} / \mathrm{g})$ & $\Delta \mathbf{H}_{\text {total }}(\mathbf{J}$ & tallinity(\%) \\
\hline PET & - & - & 112.5 & 4.07 & 254.7 & 46.1 & 50.2 & $36 \%$ \\
\hline PET/PCA0 & - & - & 122.6 & 1.11 & 254.9 & 10.2 & 11.3 & $29 \%$ \\
\hline A1 & - & - & 123.9 & 1.29 & 252.9 & 8.74 & 10.0 & $27 \%$ \\
\hline $\begin{array}{ll}30 / 70 & \text { A5 }\end{array}$ & 86.1 & 0.10 & - & - & 249.1 & 2.17 & 2.27 & $7.8 \%$ \\
\hline РET/PCB0 & 83.4 & 0.24 & 120.7 & 0.17 & 252.4 & 2.60 & 2.84 & $26 \%$ \\
\hline B1 & 84.6 & 0.16 & 120.6 & 0.13 & 242.4 & 0.73 & 1.02 & $10 \%$ \\
\hline $10 / 90$ B5 & $-^{\mathrm{a}}$ & $-^{\mathrm{a}}$ & $-^{\mathrm{a}}$ & $-^{\mathrm{a}}$ & 241.8 & 0.44 & 0.44 & $9.4 \%$ \\
\hline \multicolumn{9}{|c|}{ a - too small to be observed; } \\
\hline & & & & & & & & \\
\hline & & & & & & & & \\
\hline
\end{tabular}

